University of Nebraska - Lincoln

DigitalCommons@University of Nebraska - Lincoln

USDA Forest Service / UNL Faculty Publications U.S. Department of Agriculture: Forest Service -National Agroforestry Center

2011

\title{
Laboratory assays of select candidate insecticides for control of Dendroctonus ponderosae
}

Christopher J. Fettig

USDA Forest Service, cfettig@fs.fed.us

Christopher J. Hayes

USDA Forest Service

Stephen R. McKelvey

USDA Forest Service

Sylvia R. Mori

USDA Forest Service

Follow this and additional works at: https://digitalcommons.unl.edu/usdafsfacpub

Part of the Forest Sciences Commons

Fettig, Christopher J.; Hayes, Christopher J.; McKelvey, Stephen R.; and Mori, Sylvia R., "Laboratory assays of select candidate insecticides for control of Dendroctonus ponderosae" (2011). USDA Forest Service / UNL Faculty Publications. 142.

https://digitalcommons.unl.edu/usdafsfacpub/142

This Article is brought to you for free and open access by the U.S. Department of Agriculture: Forest Service -National Agroforestry Center at DigitalCommons@University of Nebraska - Lincoln. It has been accepted for inclusion in USDA Forest Service / UNL Faculty Publications by an authorized administrator of DigitalCommons@University of Nebraska - Lincoln. 


\title{
Laboratory assays of select candidate insecticides for control of Dendroctonus ponderosae
}

\author{
Christopher J Fettig, ${ }^{\text {a* }}$ Christopher J Hayes, ${ }^{\text {b }}$ Stephen R McKelvey ${ }^{\text {b }}$ \\ and Sylvia R Moric
}

\begin{abstract}
BACKGROUND: The mountain pine beetle, Dendroctonus ponderosae Hopkins (Coleoptera: Curculionidae, Scolytinae), is the most destructive bark beetle in western North America. Dendroctonus ponderosae can be prevented from successfully colonizing and killing individual trees by ground-based sprays of insecticides applied directly to the tree bole. However, the future availability of several active ingredients, including carbaryl which is most commonly used in the western United States, is uncertain. Two novel insecticides, cyantraniliprole [Cyazypyr ${ }^{\mathrm{TM}}-\mathrm{OD}$ (oil dispersion) and Cyazypyr ${ }^{\mathrm{TM}}$-SC (suspension concentrate)] and chlorantraniliprole (Rynaxypyr ${ }^{\circledR}$ ), and carbaryl were assayed in both filter paper and topical assays.

RESULTS: Compared with $20000 \mathrm{mg} \mathrm{L}^{-1}$ carbaryl (i.e. the maximum label rate for solutions applied to conifers for protection from bark beetle attack in the western United States), cyantraniliprole OD caused similar rates of mortality in $D$. ponderosae adults at $\mathbf{4 0 0}$-fold weaker concentrations in both bioassays, while cyantraniliprole SC caused similar rates of mortality at 40-fold weaker concentrations. Probit analyses confirmed that $D$. ponderosae is most sensitive to cyantraniliprole OD, while chlorantraniliprole was effective at concentrations similar to carbaryl.

CONCLUSIONS: These results suggest that lower concentrations of carbaryl have merit for field testing than have been previously considered. While cyantraniliprole and chlorantraniliprole have similar modes of action, cyantraniliprole OD appears to have greater promise for protecting individual trees from mortality attributed to $D$. ponderosae attack and should be evaluated in field studies.

Published 2011 by John Wiley \& Sons, Ltd.
\end{abstract}

Keywords: carbaryl; chemical control; chlorantraniliprole; cyantraniliprole; Dendroctonus ponderosae; mountain pine beetle; Scolytinae

\section{INTRODUCTION}

About $8 \%$ of forests in the United States are classified at risk (defined as $>25 \%$ of stand density will die in the next 15 years) to insect and disease outbreaks. ${ }^{1}$ The mountain pine beetle, Dendroctonus ponderosae Hopkins (Coleoptera: Curculionidae, Scolytinae), is ranked most damaging of all agents considered. ${ }^{1}$ This species ranges throughout British Columbia and Alberta, Canada, most of the western United States and into northern Mexico, and colonizes several pine species, most notably lodgepole pine, Pinus contorta Dougl. ex Loud., ponderosa pine, $P$. ponderosa Dougl. ex Laws., sugar pine, P. lambertiana Dougl., whitebark pine, $P$. albicaulis Engelm., and western white pine, $P$. monticola Dougl. ex D. Don. ${ }^{2}$ Dendroctonus ponderosae typically initiates and concentrates attacks in the lower tree bole, facilitating host colonization through the use of aggregation pheromones. ${ }^{3}$ A tree is considered 'mass attacked' when sufficient numbers of beetles are present to overcome host tree defenses. Partial attacks, often referred to as 'strip attacks', may occur if sufficient numbers of beetles are not present, and these trees may survive for many years. In brief, tree death occurs by girdling of the phloem (i.e. layers of cells just inside the bark that transport photosynthate within the tree) by both colonizing adults and developing larvae. ${ }^{3}$
In the western United States, $>5.5$ million ha were impacted by D. ponderosae during $2001-2006,{ }^{4}$ while $>9$ million ha have been impacted in British Columbia, Canada, since $2003 .^{5}$

Attacks by $D$. ponderosae reduce tree growth and hasten decline (as a result of strip attacks), cause tree mortality and subsequent replacement by other tree species and may impact timber and fiber production, water quality and quantity, fish and wildlife populations, recreation, grazing capacity, real estate values, biodiversity, carbon storage, endangered species and cultural resources. Trees located in residential, recreational (e.g. campgrounds) or administrative sites are particularly susceptible to attacks by $D$. ponderosae as a result of increased amounts of stress associated with drought, soil compaction, mechanical

\footnotetext{
Correspondence to: Christopher J Fettig, Pacific Southwest Research Station USDA Forest Service, 1731 Research Park Drive, Davis, CA 95618, USA. E-mail: cfettig@fs.fed.us

a Pacific Southwest Research Station, USDA Forest Service, Davis, CA, USA

b Pacific Southwest Research Station, USDA Forest Service, Placerville, CA, USA

c Pacific Southwest Research Station, USDA Forest Service, Berkeley, CA, USA
} 
injury or vandalism. ${ }^{6}$ Tree losses in these environments pose potential hazards to public safety. Costs associated with hazard tree removal and litigation can be substantial, ${ }^{7}$ and property values may be significantly reduced by mortality of adjacent shade and ornamental trees. ${ }^{8}$ The value of these trees, the cost of removal and the loss of aesthetic value often justify protecting individual trees with insecticides, particularly during bark beetle outbreaks.

Protection of individual trees from attack by $D$. ponderosae and other bark beetles in the western United States has historically involved applications of liquid formulations of contact insecticides to the tree bole using hydraulic sprayers. For example, benzene hexachloride, fenitrothion and chlorpyrifos were registered for this use, but all three registrations have been canceled or withdrawn. Several pyrethroids (e.g. permethrin and bifenthrin) are registered and effective for protecting individual trees from attacks by bark beetles, but generally provide protection for a period of $\leq 1$ year with a single application.,9-11 Several researchers have reported that carbaryl is still one of the most effective, economically viable, and ecologically compatible insecticides available for protecting individual trees from bark beetle attack in the western United States, ${ }^{10}$ and generally provides protection for a period of 2 years with a single application. ${ }^{6,10,11}$ As a result, carbaryl is commonly used to protect trees from attacks by $D$. ponderosae, but its use on trees is continually being challenged, and it is uncertain how long carbaryl will retain registration for this use. This situation emphasizes the need for assuring that effective insecticide treatments are available for protecting individual trees from bark beetle attacks. As these tools are applied in a preventive manner (i.e. in order to prevent tree mortality by protecting trees prior to attack), bark beetles must be killed or incapacitated quickly before successful tree colonization and girdling of the phloem tissue occurs.

The objective of this study was to determine the toxicity to $D$. ponderosae adults of two novel insecticides, cyantraniliprole $\left(\right.$ Cyazypyr $^{\mathrm{TM}}$ ) and chlorantraniliprole (Rynaxypyr ${ }^{\circledR}$ ), which are being considered for future field testing, and carbaryl in both filter paper and topical assays conducted in the laboratory. Chlorantraniliprole recently obtained registration (2006) in the United States for cotton, grapes, tree fruits and certain vegetables as a reducedrisk insecticide (Insecticide Resistance Action Committee, 2009) and controls insect pests through a unique mode of action by activating ryanodine receptors (RyR), which play a critical role in muscle function. Ryanodine receptors act as selective ion channels, modulating the release of calcium. Chlorantraniliprole binds to the RyR, causing uncontrolled release and depletion of internal calcium, thus preventing further muscle contraction and ultimately leading to death. Chlorantraniliprole is of very low toxicity to vertebrates, and results are favorable for a range of tests, including carcinogenicity, mutagenicity, neurotoxicity and reproductive toxicity. ${ }^{12,13}$ Cyantraniliprole is a second-generation RyR insecticide with a similar mode of action to chlorantraniliprole. Registration of cyantraniliprole is expected by 2012 in the United States for several agricultural crops. Carbaryl is registered for control of a wide range of insect pests on $>100$ agricultural crops and non-crop uses. Carbaryl is an acetylcholinesterase inhibitor preventing the cholinesterase enzyme from breaking down acetylcholine, increasing both the level and duration of action of the neurotransmitter acetylcholine, which leads to rapid twitching, paralysis and ultimately death.

\section{MATERIALS AND METHODS}

\subsection{Collection of insects}

Live $D$. ponderosae adults were obtained through collections in 16-unit multiple-funnel traps baited with $D$. ponderosae lures consisting of trans-verbenol, exo-brevicomin, myrcene and terpinolene (Synergy Semiochemicals Corp., Burnaby, BC). A total of 30 traps were deployed in two locations, 20 on the Eldorado National Forest, CA $\left(38.49^{\circ} \mathrm{N}, 120.15^{\circ} \mathrm{W} ; 2028 \mathrm{~m}\right.$ elevation) and ten on the Lake Tahoe Basin Management Unit, CA $\left(38.53^{\circ} \mathrm{N}\right.$, $119.54^{\circ} \mathrm{W} ; 2390$ m elevation). Trap locations were selected on the basis of ground surveys indicating that $D$. ponderosae was actively colonizing $P$. contorta in the area. Traps were hung on $3 \mathrm{~m}$ metal poles with collection cups $80-100 \mathrm{~cm}$ above the ground. Crumpled paper towels were placed in each collection cup to reduce the number of beetles that escaped capture and to decrease damage to and predation of $D$. ponderosae by creating a diverse substrate and refugia (Hayes $J$, private communication, 2010). Captures were collected daily (as needed) from 1 July to 5 August 2010 and immediately transported to the laboratory $(\approx 60$ and $108 \mathrm{~km}$ from collection sites respectively) in wax-coated paper containers (960 mL; Solo Cup Co., Highland Park, IL) with four small circular holes ( $\approx 0.8 \mathrm{~mm}$ diameter) placed in the top to facilitate ventilation. These containers were placed in coolers containing blue ice (Rubbermaid $^{\circledR}$, Huntersville, NC) during transport. Upon return to the lab, specimens were identified, sorted [i.e. damaged (loss of any appendages) or weakened (did not immediately walk) individuals were discarded] and stored in wax-coated paper containers (see above) containing a paper towel moistened with distilled water to prevent dehydration (Hayes $\mathrm{JL}$, private communication, 2010). Beetles were stored for up to $48 \mathrm{~h}$ in a refrigerator at $5^{\circ} \mathrm{C}$ until enough ( 210 beetles) were accumulated to complete a single replicate. Beetles that were not assayed within $48 \mathrm{~h}$ were discarded.

\subsection{Treatments}

Four insecticide treatments and an untreated control were assayed. Five tenfold serial dilutions of each insecticide were prepared in distilled water. Two formulations of cyantraniliprole [Cyazypyr ${ }^{\mathrm{TM}}$ OD (oil dispersion) and Cyazypyr ${ }^{\mathrm{TM}}$-SC (suspension concentrate); research and demonstration formulations; El du Pont de Nemours and Company, Stine-Haskell Research Center, Crop Protection Products, Newark, DE] were assayed at 0.5, 5, 50, 500 and $5000 \mathrm{mg}$ $\mathrm{Al} \mathrm{L}^{-1}$. Chlorantraniliprole [Rynaxypyr ${ }^{\circledR}$ (Coragen $\left.{ }^{\circledR} \mathrm{SC}\right)$; El du Pont de Nemours and Company, Wilmington, DE; EPA Reg. No. 352-729] was also assayed at 0.5, 5, 50, 500 and $5000 \mathrm{mg} \mathrm{Al} \mathrm{L}^{-1}$. Carbaryl (Sevin ${ }^{\circledR}$ SL; Bayer Environmental Science, Montvale, NJ; EPA Reg. No. 432-1227) was assayed at 20, 200, 2000, 20000 (maximum labeled rate in the United States) and $200000 \mathrm{mg} \mathrm{Al} \mathrm{L}^{-1}$ and included as an internal standard owing to its common use for protecting trees from bark beetle attack in the western United States.

\subsection{Filter paper assay}

A quantity of $1 \mathrm{~mL}$ of each solution (e.g. $20000 \mathrm{mg} \mathrm{L}^{-1}$ carbaryl) was applied with a micropipette to one $9 \mathrm{~cm}$ diameter glass microfiber filter disc (Whatman 934-AH, $1.5 \mu \mathrm{m}$ pore size; ColeParmer, Vernon Hills, IL), stored in a $10 \mathrm{~cm}$ diameter sterile polystyrene petri dish (Cole-Parmer) and allowed to dry in a fume hood for $2 \mathrm{~h}$ (four insecticide treatments $\times$ five concentrations + untreated control $=21$ dishes per replicate). Prepared petri dishes (i.e. those containing insecticide-treated and dried glass microfiber filter discs) were stored for later use in airtight plastic bags at $5^{\circ} \mathrm{C}$ for $\leq 7$ days, after which time they were discarded. 
The experiment was replicated 8 times ( $N=168$ dishes). Ten $D$. ponderosae were randomly selected from recently captured individuals (i.e. stored up to $48 \mathrm{~h}$ ) and placed on each treated filter paper in the bottom of the petri dish ( $N=1680$ beetles). Small holes ( $\approx 0.8 \mathrm{~mm}$ diameter) were drilled into the tops of each petri dish to facilitate ventilation. Petri dishes were stored in a large fume hood (Model No. 4863 000; Labconco Corp., Kansas City, MO) with airflow of $4.1 \mathrm{~m}^{3} \mathrm{~min}^{-1}$ under static abiotic conditions $\left(\approx 20^{\circ} \mathrm{C}, \mathrm{RH}=45 \%\right.$, $14.5 \mathrm{~h}$ light), and the number of dead and moribund individuals (i.e. defined as those that could no longer right themselves and walk) was recorded within each dish at 6,12 , $24,48,96,120,144$ and $168 \mathrm{~h}$. Dead individuals were immediately removed from petri dishes, and the gender was later determined through examination of the seventh abdominal tergite ${ }^{14}$ for the presence of an angular margin (serving as a stridulating organ in males) with a compound microscope.

\subsection{Topical assays}

Ten $D$. ponderosae were randomly selected from recently captured individuals (i.e. stored for up to $48 \mathrm{~h}$ ) and treated topically with $0.5 \mu \mathrm{L}$ of each insecticide solution to the ventral surface of the mesothorax of each $D$. ponderosae using a micropipette. Treated $D$. ponderosae were then transferred into petri dishes (four insecticide treatments $\times$ five concentrations + untreated control $=21$ dishes per replicate; ten $D$. ponderosae per dish) lined with untreated $9 \mathrm{~cm}$ diameter glass microfiber filter discs (Whatman 934-AH). Micropipette tips were discarded after application of each solution. Petri dishes were then stored in a large fume hood under static conditions (Section 2.3), and the number of dead and moribund individuals was recorded within each dish at $6,12,24,48,96,120$, 144 and $168 \mathrm{~h}$. The experiment was replicated 8 times $(N=1680$ beetles). As above, dead individuals were immediately removed from petri dishes and the gender was determined through examination of the seventh abdominal tergite. ${ }^{14}$

\subsection{Statistical analysis}

\subsubsection{Survival curves}

The life-table method ${ }^{15}$ was used to estimate the survival probability of $D$. ponderosae subjected to different doses of each insecticide, and to compare the survival curves from filter paper and topical assays. The non-parametric Mantel log-rank test with the Dunnet adjustment was used to compare treatment doses with $20000 \mathrm{mg} \mathrm{L}^{-1}$ carbaryl and the untreated control. The SAS (SAS v.9.2; SAS Institute, Cary, NC) Lifetest procedure was used to estimate the survival probabilities and confidence intervals, and to test the multiple comparisons.

\subsubsection{Lethal doses}

To compare dose assays, a logistic regression model with the probit link from the family of the generalized linear model (GLM) ${ }^{16,17}$ was fitted to the data (number of dead $D$. ponderosae from ten initial $D$. ponderosae for each replicate), assuming a binomial distribution. The statistical model for the proportion of dead beetles for each time period $(0-6,0-12,0-24,0-48$ and $0-72 \mathrm{~h}$; because of the high mortality rates after $72 \mathrm{~h}$, longer time periods were not included in this analysis) is as follows:

$$
P_{i j}=\Phi\left[a_{i j}+b_{i j} \times \log (\text { dose })\right]
$$

where $P_{i j}$ is the probability of mortality at the end of a given period $j$ for treatment $i$ for a given dose, $\Phi$ is the cumulative standard normal distribution function, $a_{i j}$ and $b_{i j}$ are the intercept and slope for the respective treatment $i$ and log(dose) is the logarithm of the dose (the log function of the dose improved the fitting). For each time period $j$ and treatment $i, \mathrm{LC}_{50}$ was calculated as

$$
\mathrm{LC}_{50}=\mathrm{e}^{-\frac{a_{i j}}{b_{i j}}}
$$

The SAS NLMIXED procedure was used to estimate the coefficients and compare the $L C_{50}$ values among treatments at a given time period. The Bonferroni approach was used for pairwise comparison tests to attain an experiment-wise error rate equal to 0.05 .

\section{RESULTS AND DISCUSSION}

\subsection{Survival probability}

In the field, the effectiveness of carbaryl for protecting individual trees from $D$. ponderosae attack has been well established for some time. ${ }^{6,10,11,18-22}$ For example, Shea and McGregor ${ }^{22}$ evaluated $0.5,1.0$ and $2.0 \%$ carbaryl and found that all concentrations and formulations were effective for protecting $P$. contorta from $D$. ponderosae attack for 1 year. In the filter paper assay, no significant differences were found in survival probability between $20000 \mathrm{mg} \mathrm{L}^{-1}$ carbaryl (i.e. the maximum label rate typically used in commercial applications, hereafter referred to as the internal standard) and other concentrations of carbaryl until the concentration was reduced $1000 \times\left(20 \mathrm{mg} \mathrm{L}^{-1}\right)$ (Table 1$)$. The survival of $D$. ponderosae exposed to $20 \mathrm{mg} \mathrm{L}^{-1}$ of carbaryl was $>70 \%$ at $24 \mathrm{~h}$ (Fig. 1) and was not significantly different from the untreated control (Table 1). In the topical assay there was no significant difference in survival probability between the internal standard and $200000 \mathrm{mg} \mathrm{L}^{-1}$ of carbaryl, but there was significantly higher survival probability with carbaryl concentrations of $\leq 2000 \mathrm{mg} \mathrm{L}^{-1}$ compared with the internal standard (Table 1). Survival probabilities of $D$. ponderosae exposed to $\leq 20 \mathrm{mg} \mathrm{L}^{-1}$ of carbaryl in topical assays was $>85 \%$ at $24 \mathrm{~h}$ (Fig. 2). When compared with the untreated control, $D$. ponderosae exposed to carbaryl residues of $\geq 2000 \mathrm{mg} \mathrm{L}^{-1}$ in the topical assay had significantly lower survival probability (Table 1). While significant data exist on the effectiveness of carbaryl for protecting individual trees from attack by $D$. ponderosae, these are the first data detailing its toxicity to $D$. ponderosae in laboratory assays. Results from the filter paper assays suggest that lower concentrations than the internal standard $(100 \times$ lower, $200 \mathrm{mg} \mathrm{L}^{-1}$ ) could be considered for field testing, but this is not supported by the topical assays (where lower concentrations exhibited significantly higher survival probabilities).

Cyantraniliprole is believed to hold great promise for insect control, based on its properties of improved plant mobility, significant activity on Lepidopteran pests and an increased spectrum of activity that is known to include members of Hemiptera. ${ }^{23}$ However, no data have hitherto been published on its effectiveness for controlling forest Coleoptera, probably because the chemistry was only recently developed. Similar trends were observed for cyantraniliprole OD (as compared with the internal standard) in both filter paper and topical assays (Table 1). Cyantraniliprole OD had significantly higher survival probability than the internal standard at concentrations of $\leq 50$ $\mathrm{mg} \mathrm{L}^{-1}$ (Table 1). Survival rates of $D$. ponderosae exposed to $\leq 5$ $\mathrm{mg} \mathrm{L}^{-1}$ in filter paper assays were $>60 \%$ at $24 \mathrm{~h}$ (Fig. 1 ). No significant difference was observed between the internal standard and $\geq 500 \mathrm{mg} \mathrm{L}^{-1}$ of cyantraniliprole OD. In the filter paper assay, 
Table 1. The $\chi^{2}$ values for pairwise comparisons, using the log-rank test, of survival probabilities of Dendroctonus ponderosae, comparing treatments with $20000 \mathrm{mg} \mathrm{L}^{-1}$ carbaryl (internal standard; maximum label rate typically used in commercial applications) and the untreated control, Placerville, California $^{\mathrm{a}}$

\begin{tabular}{|c|c|c|c|c|c|}
\hline \multirow[b]{2}{*}{ Insecticide } & \multirow[b]{2}{*}{ Conc. $\left(\mathrm{mg} \mathrm{L}^{-1}\right)$} & \multicolumn{2}{|c|}{ Filter paper $\left(\chi^{2}\right)$} & \multicolumn{2}{|c|}{ Topical $\left(\chi^{2}\right)$} \\
\hline & & Carbaryl (20000 $\left.\mathrm{mg} \mathrm{L}^{-1}\right)$ & Untreated control & Carbaryl (20000 mg L $\left.{ }^{-1}\right)$ & Untreated control \\
\hline Control & - & $137.1^{*}$ & - & $84.8^{*}$ & - \\
\hline \multirow[t]{5}{*}{ Carbaryl } & 20 & $106.2^{*}$ & 2.2 & $101.8^{*}$ & 0.5 \\
\hline & 200 & 2.6 & $105.2^{*}$ & $90.7^{*}$ & 0.02 \\
\hline & 2000 & 0.1 & $131.4^{*}$ & $34.4^{*}$ & $11.8^{*}$ \\
\hline & 20000 & - & $138.7^{*}$ & - & $84.8^{*}$ \\
\hline & 200000 & 2.5 & $104.7^{*}$ & 1.2 & $104.4^{*}$ \\
\hline Cyantraniliprole & 0.5 & $166.8^{*}$ & 1.0 & $126.5^{*}$ & 3.7 \\
\hline \multirow[t]{4}{*}{ OD } & 5 & $84.6^{*}$ & 6.7 & $97.0^{*}$ & 0.4 \\
\hline & 50 & $29.1^{*}$ & $41.6^{*}$ & $98.3^{*}$ & 0.4 \\
\hline & 500 & 4.7 & $94.1^{*}$ & 7.1 & $43.3^{*}$ \\
\hline & 5000 & 2.0 & $108.4^{*}$ & 0.3 & $94.7^{*}$ \\
\hline Cyantraniliprole & 0.5 & $136.8^{*}$ & 0.02 & $97.4^{*}$ & 0.4 \\
\hline \multirow[t]{4}{*}{ SC } & 5 & $70.5^{*}$ & $11.4^{*}$ & $81.7^{*}$ & 0.03 \\
\hline & 50 & $15.5^{*}$ & $62.0^{*}$ & $84.0^{*}$ & 0.02 \\
\hline & 500 & $13.7^{*}$ & $65.6^{*}$ & $32.0^{*}$ & $13.0^{*}$ \\
\hline & 5000 & 5.7 & $89.3^{*}$ & 0.5 & $72.9^{*}$ \\
\hline \multirow[t]{5}{*}{ Chlorantraniliprole } & 0.5 & $134.7^{*}$ & 0.2 & $93.3^{*}$ & 0.2 \\
\hline & 5 & $146.8^{*}$ & 0.1 & $99.2^{*}$ & 0.5 \\
\hline & 50 & $63.3^{*}$ & $14.6^{*}$ & $108.5^{*}$ & 1.2 \\
\hline & 500 & $32.2^{*}$ & $37.1^{*}$ & $84.4^{*}$ & 0.01 \\
\hline & 5000 & $22.3^{*}$ & $49.8^{*}$ & 3.3 & $54.7^{*}$ \\
\hline
\end{tabular}

concentrations of $\geq 50 \mathrm{mg} \mathrm{L}^{-1}$ of cyantraniliprole OD had lower survival probability than the untreated control, while in the topical assay the $50 \mathrm{mg} \mathrm{L}^{-1}$ concentration was not significantly different from the untreated control (Table 1). In the topical assay, $D$. ponderosae exposed to concentrations of $\leq 50 \mathrm{mg} \mathrm{L}^{-1}$ had survival rates of $>85 \%$ at $24 \mathrm{~h}$ (Fig. 2). In both assays, cyantraniliprole SC had significantly higher survival probability than the internal standard in all concentrations but $5000 \mathrm{mg} \mathrm{L}^{-1}$ (Table 1, Figs 1 and 2). When compared with the untreated control, cyantraniliprole SC had lower survival probability at concentrations of $\geq 5 \mathrm{mg} \mathrm{L}^{-1}$ in the filter paper assay, but only at concentrations of $\geq 500 \mathrm{mg} \mathrm{L}^{-1}$ in the topical bioassay. In the topical assay, $D$. ponderosae exposed to concentrations of $\leq 50 \mathrm{mg} \mathrm{L}^{-1}$ had $>85 \%$ survival at $24 \mathrm{~h}$ (Fig. 2).

While the toxicity of chlorantraniliprole to Lepidoptera is becoming well documented, ${ }^{24,25}$ few data are published on its effect on Coleoptera. A recent study ${ }^{26}$ reported that surface drenches of chlorantraniliprole significantly reduced the number of black vine weevil, Otiorhynchus sulcatus (F.) (Coleoptera: Curculionidae), larvae in Sedum plants by $92 \%$ compared with the untreated control, but was ineffective for controlling adults. In the present study, chlorantraniliprole had significantly higher survival probability than the internal standard at all concentrations evaluated in the filter paper assay, and in all but the highest concentration ( $5000 \mathrm{mg} \mathrm{L}^{-1}$ ) in the topical assay. When compared with the untreated control, chlorantraniliprole had significantly lower survival probability at concentrations of $\geq 50 \mathrm{mg} \mathrm{L}^{-1}$ in the filter paper assay, but only the highest concentration was significantly different from the untreated control in the topical assay (Table 1). Survival rates of $D$. ponderosae exposed to $\leq 500$ $\mathrm{mg} \mathrm{L}^{-1}$ in topical assays were $>80 \%$ after $24 \mathrm{~h}$ (Fig. 2). These results suggest that, while chlorantraniliprole and cyantraniliprole have similar modes of action, the latter holds greater promise for controlling $D$. ponderosae adults and for protecting individual trees from $D$. ponderosae attack.

\subsection{Comparisons of $\mathrm{LC}_{\mathbf{5 0}}$}

In the filter paper assay, mean LC $_{50}$ values ranged from 3.0 to $132.9 \mathrm{mg} \mathrm{L}^{-1}$ for cyantraniliprole SC $(24 \mathrm{~h})$ and carbaryl $(12 \mathrm{~h})$ respectively (Table 2 ). In the topical assays, mean $\mathrm{LC}_{50}$ values ranged from 141.5 to $6298.9 \mathrm{mg} \mathrm{L}^{-1}$ for cyantraniliprole OD $(24 \mathrm{~h})$ and chlorantraniliprole $(12 \mathrm{~h}$ ) respectively (Table 2 ). Cyantraniliprole OD and cyantraniliprole SC had the lowest $\mathrm{LC}_{50}$ estimates, and only differed from one another in the $12 \mathrm{~h}$ topical assay analysis, in which the oil dispersed (OD) formulation was more toxic to $D$. ponderosae. The oil dispersed formulation may have allowed better adherence of cyantraniliprole to the beetle's venter and/or enhanced penetration of the active ingredient through the insect cuticle, thereby increasing toxicity in the topical $(12 \mathrm{~h})$ assay. On the other hand, $\mathrm{LC}_{50}$ values for carbaryl and chlorantraniliprole were not significantly different, but carbaryl had significantly higher $\mathrm{LC}_{50}$ values than cyantraniliprole $\mathrm{OD}$ in all analyses (Table 2). Chlorantraniliprole had the highest $\mathrm{LC}_{50}$ estimates of all treatments (Table 2).

\subsection{Differences due to gender}

In $D$. ponderosae, host colonization is initiated by females and mediated through aggregation pheromones ${ }^{27-29}$ and host 


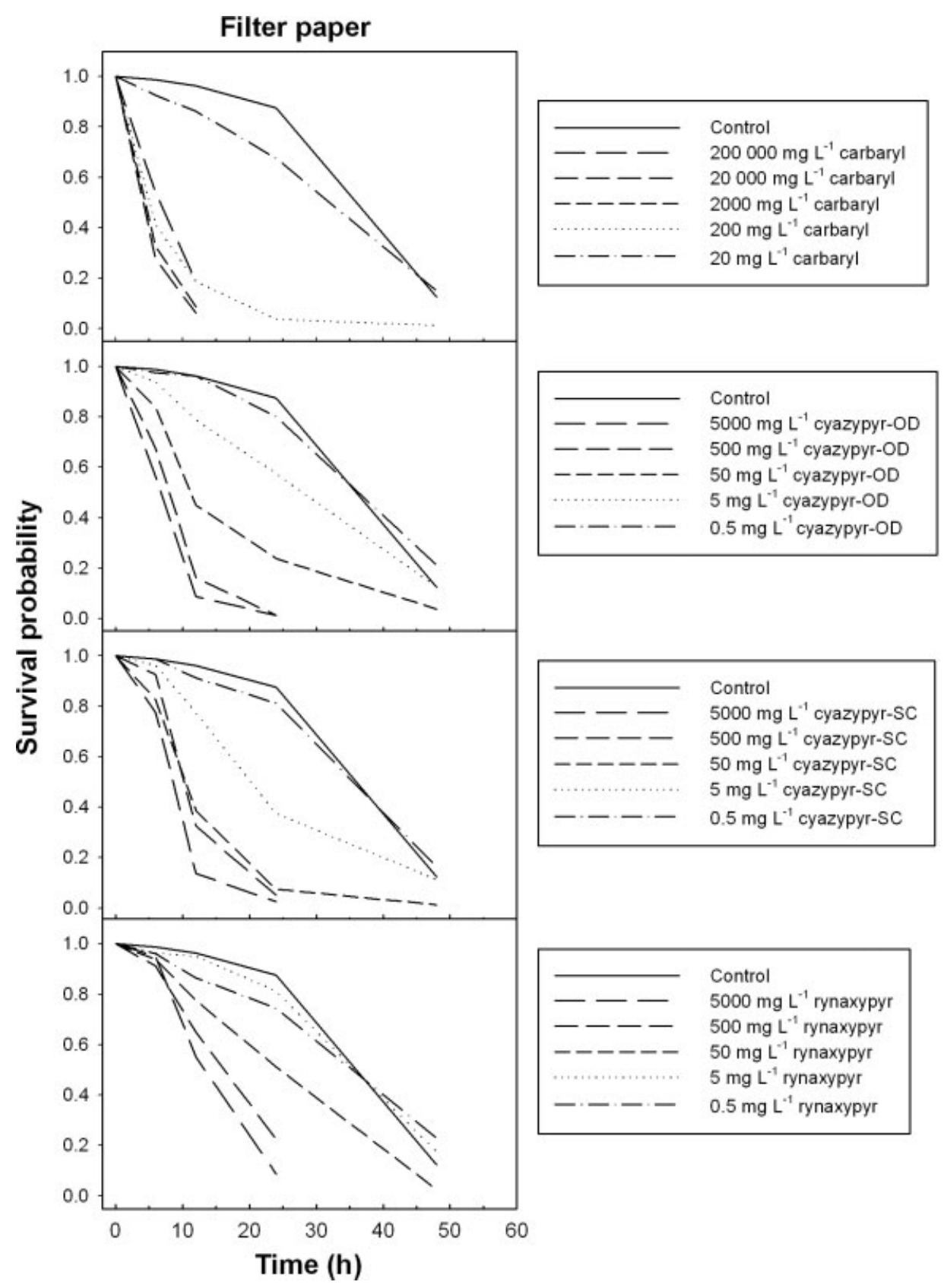

Figure 1. Survival probability curves for Dendoctronus ponderosae for carbaryl, cyantraniliprole (Cyazypyr) and chlorantraniliprole (Rynaxypyr) in the filter paper assay, Placerville, California.

kairomones. In this regard, it is obvious that, when evaluating tools for protecting trees from $D$. ponderosae attack, gender effects may be important. The results in the present analyses with respect to gender were inconsistent. In the filter paper assay there were significant differences in $\mathrm{LC}_{50}$ estimates owing to gender for cyantraniliprole OD and chlorantraniliprole, with males being more sensitive than females (lower LC $_{50}$ estimates) in both cases (Table 3). However, in the topical assay, no gender effects were observed (Table 3 ).

\section{CONCLUSION}

Recently, the US Environmental Protection Agency received voluntary cancellation requests for several uses of carbaryl (USA
Federal Register, 20 August 2008), including backpack sprayer applications and liquid formulations to residential lawns. These actions have heightened concerns that the availability of carbaryl for protecting individual trees from bark beetle attack may be limited in the future. To the authors' knowledge, these are the first data evaluating the toxicity of carbaryl, cyantraniliprole and chlorantraniliprole to $D$. ponderosae in laboratory assays. While significant data exist on the effectiveness of carbaryl for protecting individual trees from attack by $D$. ponderosae, results from the filter paper assay suggest that lower concentrations have merit for field testing than have been previously considered, but this is not supported by the topical assay. Neither assay method mimics field conditions, but the authors feel that the filter paper assay more closely approximates conditions under which 


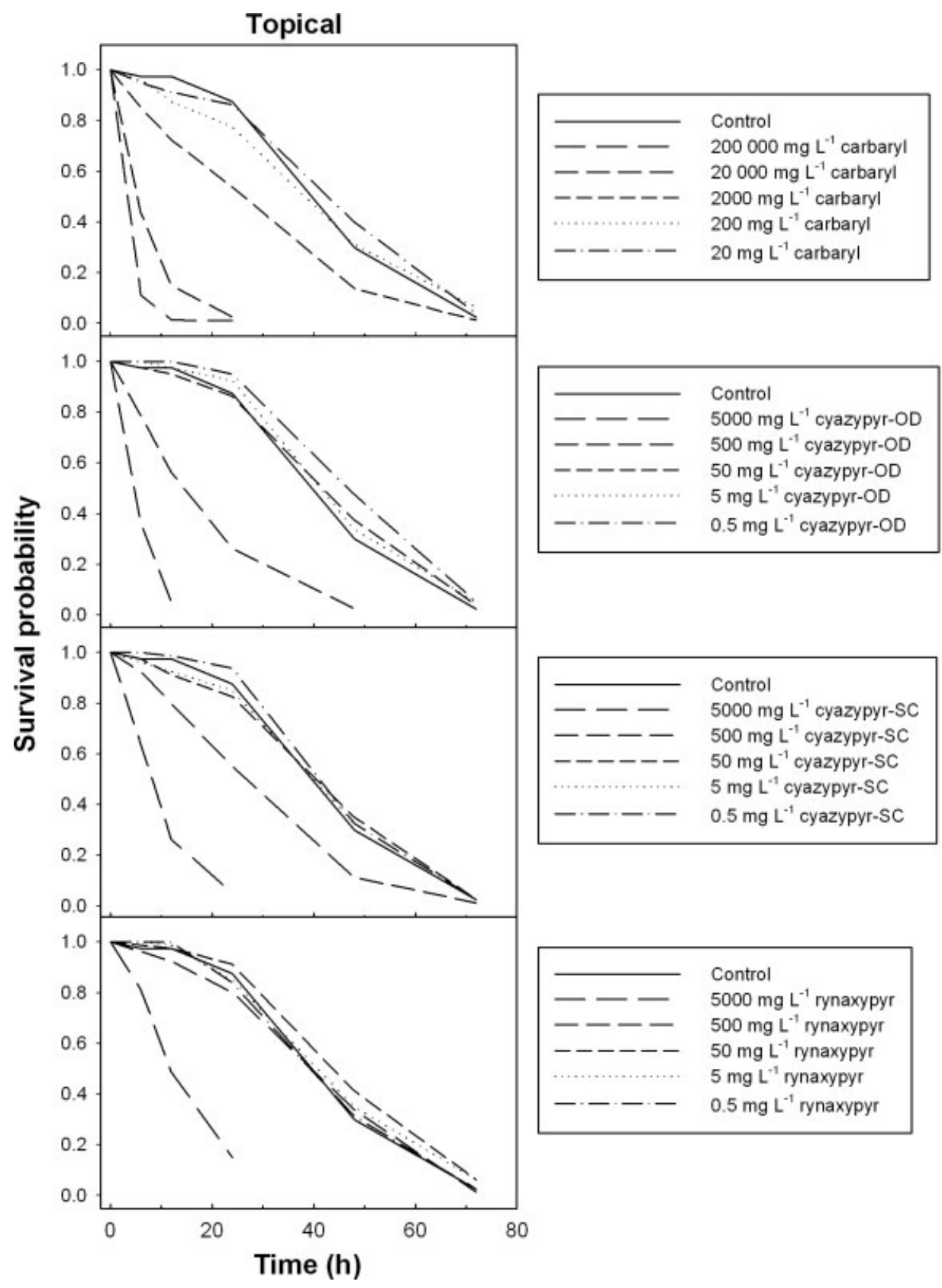

Figure 2. Survival probability curves for Dendroctonus ponderosae for carbaryl, cyantraniliprole (Cyazypyr) and chlorantraniliprole (Rynaxypyr) in the topical assay, Placerville, California.

D. ponderosae encounters toxicants during host colonization, and therefore that lower concentrations of carbaryl (e.g. $2000 \mathrm{mg} \mathrm{L}^{-1}$ ) should be evaluated in the field. The experimental formulations of cyantraniliprole and chlorantraniliprole evaluated here all proved lethal to $D$. ponderosae in both filter paper and topical assays at concentrations within the present test range, including concentrations as low as $5 \mathrm{mg} \mathrm{L}^{-1}$ in the filter paper assay. While cyantraniliprole and chlorantraniliprole have similar modes of action, cyantraniliprole OD appears to have greater promise for protecting individual trees from mortality attributed to $D$. ponderosae attack and should be evaluated in the field as an alternative to the insecticides that are currently registered. Results from the filter paper assay suggest that concentrations of $50-500 \mathrm{mg} \mathrm{L}^{-1}$ are expected to cause significant (Fig. 1) mortality of $D$. ponderosae adults within $24 \mathrm{~h}$. This is important, as beetles must be killed or incapacitated quickly before successful host colonization occurs.

\section{ACKNOWLEDGEMENTS}

The authors thank R Hernandez and J Mello (Pacific Southwest Research Station, USDA Forest Service) for technical assistance, and M Haverty (formerly Pacific Southwest Research Station), D Sherrod and J Cantlon (both DuPont Crop Protection) for their support and thoughtful discussions, without which this work would not have been possible. They also thank J Cantlon and C Dabney (Pacific Southwest Research Station) for their helpful comments on earlier versions of this manuscript. This research was 
Table 2. Comparisons of $\mathrm{LC}_{50}$ concentrations for Dendroctonus ponderosae at $12 \mathrm{~h}$ and $24 \mathrm{~h}$ after application in filter paper and topical assays, Placerville, California

\begin{tabular}{|c|c|c|c|}
\hline \multirow[b]{2}{*}{ Application } & \multirow[b]{2}{*}{ Insecticide } & \multicolumn{2}{|c|}{$\mathrm{LC}_{50}(95 \% \mathrm{CL})\left(\mathrm{mg} \mathrm{L}^{-1}\right)^{\mathrm{ab}}$} \\
\hline & & $12 \mathrm{~h}$ & $24 \mathrm{~h}$ \\
\hline \multirow[t]{4}{*}{ Filter paper } & Carbaryl & $132.9(57.2-208.7) \mathrm{a}$ & $19.1(12.1-26.2) \mathrm{a}$ \\
\hline & Cyantraniliprole OD & $46.1(26.1-66.2) b$ & $6.2(3.5-8.9) b$ \\
\hline & Cyantraniliprole SC & $56.8(26.5-87.1) a b$ & $3.0(1.5-4.4) b$ \\
\hline & Chlorantraniliprole & - & $34.9(15.1-54.7) \mathrm{a}$ \\
\hline \multirow[t]{4}{*}{ Topical } & Carbaryl & $2529.1(1433.8-3624.5)$ a & $628.7(326.5-950.8)$ ac \\
\hline & Cyantraniliprole OD & $521.8(349.4-694.2) b$ & $141.5(87.2-195.8) b$ \\
\hline & Cyantraniliprole SC & $1851.4(672.3-3030.4)$ a & $270.6(133.5-407.6) a b$ \\
\hline & Chlorantraniliprole & $6298.9(2128.9-10468.9)$ а & $1384.4(73.3-2695.5) c$ \\
\hline
\end{tabular}

Table 3. Comparisons of $\mathrm{LC}_{50}$ estimates at $24 \mathrm{~h}$ post-treatment for female and male Dendroctonus ponderosae in filter paper and topical assays, Placerville, California

\begin{tabular}{|c|c|c|c|}
\hline & \multirow[b]{2}{*}{ Insecticide } & \multicolumn{2}{|c|}{$\mathrm{LC}_{50}(95 \% \mathrm{CL})\left(\mathrm{mg} \mathrm{L}^{-1}\right)^{\mathrm{a}}$} \\
\hline & & Female & Male \\
\hline \multirow[t]{4}{*}{ Filter paper } & Carbaryl & $17.6(9.9-25.2) a$ & $22.9(10.5-35.2) \mathrm{a}$ \\
\hline & Cyantraniliprole OD & $10.1(5.8-14.4) \mathrm{a}$ & $1.7(0-3.4) b$ \\
\hline & Cyantraniliprole SC & $2.8(1.2-4.3) a$ & $3.4(0.97-5.8) a$ \\
\hline & Chlorantraniliprole & $72.7(30.8-114.6) \mathrm{a}$ & $11.0(0-22.4) b$ \\
\hline \multirow[t]{4}{*}{ Topical } & Carbaryl & $682.2(290.8-1073.6) a$ & 766.1 (136.4-1395.9) a \\
\hline & Cyantraniliprole OD & $164.8(98.2-231.4) \mathrm{a}$ & $102.0(36.8-167.2) \mathrm{a}$ \\
\hline & Cyantraniliprole SC & $257.8(91.5-424.0) \mathrm{a}$ & $301.5(79.8-523.1)$ a \\
\hline & Chlorantraniliprole & $1112.2(0.35-2224.1) \mathrm{a}$ & $1751(0-4588.7)$ a \\
\hline
\end{tabular}

supported, in part, by a grant (FS agreement 09-CO-11272164011) from El du Pont de Nemours and Company and the Pacific Southwest Research Station. This publication reports research involving pesticides. It does not contain recommendations for their use, nor does it imply that the uses discussed here have been registered. All uses of pesticides in the United States must be registered by appropriate State and/or Federal agencies before they can be recommended. This article was written and prepared by US Government employees on official time and is therefore in the public domain and not subject to copyright.

\section{REFERENCES}

1 Krist FJ, Jr, Sapio FJ and Tkacz BM, Mapping risk from forest insects and diseases. FHTET Report 2007-06, Forest Health Technology Enterprise Team, USDA Forest Service, Washington, DC, 115 pp. (2007).

2 Furniss RL and Carolin VM, Western Forest Insects. Misc. Pub. 1339, USDA Forest Service, Washington, DC, 654 pp. (1977).

3 Gibson K, Kegley S and Bentz B, Mountain pine beetle. For. Insect Dis. Leafl. 2, USDA Forest Service, Portland, OR, 12 pp. (2009).

4 Forest Insect and Disease Conditions in the United States-2006. [Online]. USDA Forest Service (2006). Available: http://www. fs.fed.us/foresthealth/technology/pdfs/ConditionsReport_06_ final.pdf [29 December 2010].
5 Westfall $\mathrm{J}$ and Ebata T, Summary of Forest Health Conditions in British Columbia - 2007. Forest Practices Branch, British Columbia Ministry of Forests, Kamloops, BC, 81 pp. (2008).

6 Haverty MI, Shea PJ, Hoffman JT, Wentz JM and Gibson KE, Effectiveness of esfenvalerate, cyfluthrin, and carbaryl in protecting individual lodgepole pines and ponderosa pines from attack by Dendroctonus spp. Res. Paper PSW-RP-237, Pacific Southwest Research Station, USDA Forest Service, Albany, CA, 12 pp. (1998).

7 Johnson DW, Tree hazards: recognition and reduction in recreation sites. Tech. Report R2-1, Rocky Mountain Region, USDA Forest Service, Lakewood, CO, 24 pp. (1981).

$8 \mathrm{McGregor} M D$ and Cole WE, Integrating management strategies for the mountain pine beetle with multiple resource management of lodgepole pine forests. Gen. Tech. Report INT-GTR-174, Intermountain Forest and Range Experiment Station, USDA Forest Service, Ogden, UT, 68 pp. (1985).

9 Shea PJ, Haverty MI and Hall RW, Effectiveness of fenitrothion and permethrin for protecting ponderosa pine from attack by western pine beetle. J Ga Entomol Sci 19:427-433 (1984).

10 Fettig CJ, Allen KK, Borys RR, Christopherson J, Dabney CP, Eager TA, et al, Effectiveness of bifenthrin (Onyx ${ }^{\mathrm{TM}}$ ) and carbaryl (Sevin ${ }^{\circledR} \mathrm{SL}$ ) for protecting individual, high-value trees from bark beetle attack (Coleoptera:Curculionidae: Scolytinae) in the western United States. J Econ Entomol 99:1691 -1698 (2006).

11 Fettig CJ, DeGomez TE, Gibson KE, Dabney CP and Borys RR, Effectiveness of permethrin plus-C (Masterline ${ }^{\circledR}$ ) and carbaryl (Sevin $\mathrm{SL}^{\circledR}$ ) for protecting individual, high-value pines from bark beetle attack. Arbor Urban For 32:247-252 (2006). 
12 Lahm GP, Selby TP, Freudenberger JH, Stevenson TM, Myers BJ, Seburyamo G, et al, Insecticidal anthranilic diamides: a new class of potent ryanodine receptor activators. Med Chem Lett 15:4898-4906 (2005).

13 Cordova D, Benner EA, Sacher MD, Rauh JJ, Sopa JS, Lahm GP, et al, Anthranilic diamides: a new class of insecticides with a novel mode of action, ryanodine receptor activation. Pestic Biochem Physiol 84:196-214 (2006).

14 Lyon RL, A useful secondary sex character in Dendroctonus bark beetles. Can Entomol 90:582-584 (1958).

15 Lee ET and Wang JW, Statistical Methods for Survival Data Analysis. Wiley-Interscience, New York, NY (2003).

16 Preisler KH and Robertson JL, Analysis of time-dose-mortality data. J Econ Entomol 82:1534-1542 (1989).

17 McCulloch CE and Searle SR, Generalized, Linear and Mixed Models. Wiley-Interscience, New York, NY (2001).

18 Smith RH, Trostle GC and McCambridge WF, Jr, Protective spray tests on three species of bark beetles in the western United States. J Econ Entomol 70:119-125 (1977).

19 McCambridge WF, Field tests of insecticides to protect ponderosa pine from the mountain pine beetle (Coleoptera: Scolytidae). J Econ Entomol 75:1080-1082 (1982).

20 Gibson KE and Bennett DD, Effectiveness of carbaryl in preventing attacks on lodgepole pine by the mountain pine beetle. J For 83:109-112 (1985).

21 Page M, Haverty Ml and Richmond CE, Residual activity of carbaryl protected lodgepole pine against mountain pine beetle, Dillon,
Colorado, 1982 and 1983. Res. Note PSW-RN-375, Pacific Southwest Research Station, USDA Forest Service, Albany, CA, 4 pp. (1985).

22 Shea PJ and McGregor MD, A new formulation and reduced rates of carbaryl for protecting lodgepole pine from mountain pine beetle attack. W J Appl For 2:114-116 (1987).

23 Lahm GP, Cordova D and Barry JD, New and selective ryanodine receptor activators for insect control. Bioorganic Med Chem 17:4127-4133 (2009).

24 Rhainds M and Sadif C, Control of bagworms (Lepidoptera: Psychidae) using contact and soil-applied systemic insecticides. J Econ Entomol 102:1164-1169 (2009).

25 Sial AA, Brunner JF and Doerr MD, Susceptibility of Choristoneura rosaceana (Lepidoptera: Tortricidae) to two new reduced-risk insecticides. J Econ Entomol 103:140-146 (2010).

26 Reding ME and Persad AB, Systemic insecticides for control of black vine weevil (Coleoptera: Curculionidae) in container- and fieldgrown nursery crops. J Econ Entomol 102:927-933 (2009).

27 Pitman GB, Vité JP, Kinzer GW and Fentiman AF, Jr, Bark beetle attractants: trans-verbenol isolated from Dendroctonus. Nature 218:168 (1968).

28 Rudinsky JA, Morgan B, Libbey LM and Putnam TB, Antiaggregativerivalry pheromone of the mountain pine beetle, and a new arrestant of the southern pine beetle. Environ Entomol 3:90-98 (1974).

29 Ryker LC and Libbey LM, Frontalin in the male mountain pine beetle. J Chem Ecol 8:1399-1409 (1982). 